\title{
RESPON SOSIAL DAN KEMAMPUAN SOSIALISASI PASIEN ISOLASI SOSIAL MELALUI MANAJEMEN KASUS SPESIALIS KEPERAWATAN JIWA
}

\author{
Fajriyati Nur Azizah ${ }^{1 *}$, Achir Yani S. Hamid ${ }^{2}$, Ice Yulia Wardani ${ }^{3}$ \\ ${ }^{* 1}$ Program Studi Ners Stikes Jenderal Achmad Yani Yogyakarta, Jl. Ringroad Barat, Ambarketawang, \\ Gamping, Sleman, Yogyakarta. Telp. (0274) 4342000. Email: fajriyatinurazizah@gmail.com, \\ ${ }^{2,3}$ Program Studi Pendidikan Spesialis Keperawatan Jiwa Fakultas IImu Keperawatan Universitas Indonesia, \\ Pondok Cina, beji, Kota Depok, Jawa Barat, 16424.
}

\begin{abstract}
Background: Social isolation is a condition of loneliness felt by the individual being unable to make contact with other people. Social isolation can result in further on the issue of fulfillment of basic needs, so it would appear hallucinations that endanger themselves and others.

Objective: The purpose of writing scientific papers to describe social changes, and socialization capabilities in social isolation's patients using nursing care management of psychiatric specialist.

Methods: Nursing orders given to 22 clients using nurses action, Social Skills Training (SST), and Cognitive-Behavioral and Social Skills Training (CBSST).

Result: Results obtained reduction in social symptoms of social isolation mark that includes withdraw behaviour, interaction difficulties, refuse to communicate with others, fail to interact with others nearby, disabillity to participate in social activities, ignoring the environtment, and mistrust with others. The result also shown the improvement of socialization patient ability.

Conclusion: : There were reduction in symptoms of social isolation obviously showed on social aspects as well as an increase in the client's ability to socialize. Recommendations of this study was to use a combination of measures such as nurses and specialist nurses Social Skills Training and Cognitive-Behavioral and Social Skills Training on clients with social isolation.
\end{abstract}

Key Words : Social Skills Training, Cognitive-Behavioral and Social Skills Training

\section{PENDAHULUAN}

Gangguan jiwa merupakan pola perilaku atau psikologis seseorang yang menyebabkan distres, disfungsi, dan penurunan kualitas hidup. ${ }^{1}$ Tahun 2009, WHO memperkirakan 450 juta jiwa di dunia mengalami gangguan jiwa, 10\% di antaranya berusia dewasa, 25\% akan mengalami gangguan jiwa pada usia tertentu selama hidupnya, dan akan terus berkembang sekitar $25 \%$ hingga tahun $2030 .^{2}$ Data Riskesdas (2013) menyebutkan bahwa prevalensi gangguan jiwa berat pada penduduk di Indonesia mencapai angka 1,7 per mil. ${ }^{3}$ Gangguan jiwa berat salah satunya adalah skizofrenia. Skizofrenia dialami lebih dari 21 juta jiwa di dunia dan umumnya banyak terjadi pada laki-laki (12 juta jiwa), sedangkan pada wanita sekitar 9 juta jiwa. ${ }^{4}$ Skizofrenia atau gangguan jiwa yang menunjukkan tanda gejala serupa skizofrenia dialami oleh 2-4 juta jiwa atau sekitar $1,1 \%$ dari total populasi penduduk dunia. $^{5}$

Kurang motivasi dan adanya penurunan kemampuan bersosialisasi yang menyebabkan isolasi sosial banyak dialami oleh pasien dengan skizofrenia. Isolasi sosial adalah kesepian yang dialami oleh individu dan dirasakan saat didorong oleh keberadaan orang lain dan sebagai 
pernyataan negatif atau mengancam.Batasan karakteristiknya antara lain tidak menganggap penting dukungan dari orang lain, afek tumpul, adanya bukti cacat (fisik atau mental), sakit, tindakan yang tidak berarti, tidak ada kontak mata, dipenuhi oleh pikiran sendiri, menunjukkan permusuhan, tindakan berulang, sedih, senang sendiri, tidak komunikatif dan menarik diri. Selain itu data subyektif yang didapat antara lain mengungkapkan perasaan sendiri, tujuan hidup yang tidak adekuat, tidak mampu memenuhi harapan orang lain, merasa berbeda dari orang lain, tidak percaya diri saat berada di hadapan orang lain. Pasien dengan penurunan kemampuan bersosialisasi menunjukkan adanya masalah berkomunikasi dengan orang lain, ketakutan akan lingkungan sosial, masalah dengan aktivitas kehidupan sehari-hari sehingga membutuhkan latihan bersosialisasi. ${ }^{6}$ Penurunan kemampuan untuk bersosialisasi lainnya yang terjadi adalah ketidakmampuan pasien untuk berkomunikasi secara efektif dengan orang lain, terutama untuk mengungkapkan dan mengonfirmasi perasaan negatif dan positif yang dialaminya, untuk meminta atau menolak permintaan orang lain yang tidak rasional dan untuk memahami hambatan-hambatan dalam berhubungan interpersonal. ${ }^{7}$

Rajkumar dan Thara, 1989; Johnstone at al, 1990; Perlick et al, 1992 menjelaskan bahwa kondisi gangguan interaksi sosial sejalan dengan perkembangan gangguan jiwa yang dialami pasien, dan kemampuan pasien beradaptasi dengan lingkungannya. ${ }^{8} \mathrm{Hal}$ ini disebabkan karena kemampuan komunikasi sangat penting dalam kehidupan, diantaranya untuk menciptakan situasi interpersonal yang positif dengan orang lain dan untuk menyelesaikan masalah hubungan interpersonal. Pasien dengan gangguan jiwa bertahan dengan ketergantungannya terhadap penurunan kemampuan bersosialisasi yang berdampak pula pada penurunan kemampuan lainnya. ${ }^{7}$ Lebih lanjutnya, isolasi sosial menyebabkan lamanya waktu rawat pasien di rumah sakit yang berdampak pada hospitalisasi,pengabaian pasien terhadap kebutuhan dasarnya seperti makan, minum, kebersihan diri dan eliminasi, dan pada akhirnya muncul halusinasi yang membahayakan diri sendiri, orang lain, dan lingkungannya. ${ }^{9}$ Pada saat pasien diterima oleh keluarga, kondisi ini akan menjadi beban bagi keluarga dan lingkungan sekitarnya. ${ }^{10}$

Social Skills Training (SST) dan Cognitive Behavioral and Social Skills Training (CBSST) merupakan psikoterapi yang dapat dilakukan untuk mengatasi masalah sosialisasi pada pasien isolasi sosial.Social Skills Training (SST) memiliki efek yang positif pada masalah kesulitan melakukan hubungan interpersonal, depresi, dan masalah konsep diri pada pasien skizofrenia. ${ }^{7}$ Sedangkan untuk CBSST, menunjukkan bahwa dengan pemberian CBSST pada klien isolasi sosial di rumah 
sakit dapat menurunkan gejala kognitif, afektif, dan perilaku klien lebih besar daripada klien yang tidak diberikan terapi tersebut. ${ }^{11}$ Penelitian lainnya menunjukkan bahwa CBSST meningkatkan fungsi kognitif dan perilaku sosial klien serta menurunkan tanda dan gejala klien yang mengalami halusinasi dan isolasi sosial. ${ }^{12}$

Pada penelitian sebelumnya, SST dilakukan sebagai terapi individu. Namun, pada manajemen asuhan keperawatan yang dilakukan pada pasien isolasi sosial ini, peneliti menggunakan kelompok sebagai salah satu media terapi untuk SST. Kelompok merupakan wahana untuk mencoba dan menemukan hubungan interpersonal yang baik, serta mempermudah individu untuk mengembangkan perilaku yang adaptif. ${ }^{13}$ Berdasarkan hal tersebut, peneliti tertarik untuk meneliti lebih lanjut tentang perubahan tanda dan gejala isolasi sosial pada aspek sosial dan kemampuan sosialisasi pada pasien isolasi sosial sebelum dan sesudah dilakukan manajemen asuhan keperawatan spesialis (SST dan CBSST).

\section{BAHAN DAN CARA PENELITIAN}

Jenis penelitian ini adalah deskriptif eksploratif menggunakan rancangan desain quasi experiment with non-equivalent control groupdan pendekatan kuantitatif crossectional. Variabel yang diteliti oleh peneliti adalah tanda dan gejala isolasi sosial pada aspek sosial dan kemampuan sosialisasi pasien dengan isolasi sosial.
Peneliti mengukur variabel tersebut pada waktu yang bersamaan. Populasi dalam penelitian ini adalah pasien dengan diagnosa keperawatan isolasi sosial yang dirawat di Ruang Utari Rumah Sakit Prof. DR. Marzoeki Mahdi (RSMM) Bogor. Subyek dalam penelitian ini berjumlah 22 orang yang memenuhi kriteria inklusi yang telah ditentukan oleh peneliti.

Kriteria inklusi yang ditetapkan oleh peneliti adalah pasien yang sedang dirawat di Ruang Utari Rumah Sakit Prof. DR. Marzoeki Mahdi Bogor, pasien yang memiliki diagnosa keperawatan isolasi sosial dan telah mendapatkan rekomendasi oleh dokter untuk mengikuti rehabilitasi, pasien yang telah mendapatkan tindakan ners generalis (terapi individu untuk pasien isolasi sosial dan Terapi Aktivitas Kelompok Sosialisasi/TAKS) di ruangan, dan pasien yang kooperatif (bersedia mengikuti proses terapi hingga selesai). Pengambilan sampel diambil dengan teknik purposive sampling yang berjumlah 22 orang. Pada kelompok pertama, 11 orang pasien diberikan tindakan ners generalis dan SST, sedangkan kelompok kedua yang berjumlah 11 pasien diberikan tindakan ners generalis dan CBSST (CBT dan SST).

Seluruh responden diberikan terapi individu untuk pasien isolasi sosial dan TAKS oleh perawat ruangan, mahasiswa praktik, dan dibantu peneliti. Sebelum dilakukan tindakan, peneliti melakukan pengkajian untuk mengidentifikasi tanda dan gejala 
isolasi sosial terutama pada aspek sosial yang meliputi perilaku menarik diri, sulit berinteraksi, enggan berkomunikasi dengan orang lain, gagal berinteraksi dengan orang lain yang ada di sebelahnya, ketidakmampuan berpartisipasi dalam kegiatan sosial, tidak peduli dengan lingkungan, dan curiga terhadap orang lain. Tanda dan gejala tersebut disesuaikan dengan ceklis/kuesioner yang telah dibuat berdasarkan modul praktik keperawatan jiwa Program Magister Keperawatan Jiwa Fakultas IImu Keperawatan Universitas Indonesia tahun 2015. Peneliti juga mengidentifikasi kemampuan sosialisasi pasien sebelum dilakukan tindakan ners generalis dan ners spesialis.

Terapi ners generalis dan CBT dilakukan di ruangan, sedangkan SST dilakukan berkelompok di unit rehabilitasi 3 kali seminggu hingga sesi SST selesai. SST terdiri dari empat sesi. Sesi pertama adalah latihan bersosialisasi, sesi kedua latihan menjalin persahabatan, sesi ketiga latihan bekerjasama dalam kelompok, dan sesi keempat latihan menghadapi situasi yang sulit. Sedangkan CBSST terdiri dari enam sesi. Sesi pertama latihan merubah pikiran negatif pertama, sesi kedua latihan merubah pikiran negatif kedua, sesi ketiga adalah latihan bersosialisasi, sesi keempat latihan menjalin persahabatan, sesi kelima latihan bekerjasama dalam kelompok, dan sesi keenam latihan menghadapi situasi yang sulit.

\section{HASIL DAN PEMBAHASAN}

\section{Karakteristik Responden}

Penelitian menunjukkan semua pasien di Ruang Utari berjenis kelamin perempuan (100\%). Ruang Utari merupakan ruangan yang dikhususkan untuk pasien perempuan kelas III. Jenis kelamin tidak memengaruhi secara signifikan terjadinya gangguan jiwa. ${ }^{14}$ Wanita lebih cenderung mengalami gejala yang lebih ringan dibandingkan pria. Sejumlah $72,73 \%$ pasien perempuan tersebut berusia dewasa (25-60 tahun) dan masuk pada tahap perkembangan psikososial intimasi. ${ }^{15}$ Tahap psikososial yang penting di usia ini adalah mampu membina hubungan baik dengan masyarakat, hubungan kerja, dan hubungan yang intim dengan orang lain. Jika tidaktercapai, individu akan terisolasi dan sulit membina hubungan. ${ }^{14,16}$ Berkaitan dengan tahap psikososial ini sebagian besar responden tidak bekerja $(36,36 \%)$ dan berstatus menikah (45,46\%).Pekerjaan erat kaitannya dengan status ekonomi klien. Pekerjaan dapat menjadi sumber masalah pada sebagian orang jika tidak segera diatasi dan pada akhirnya menyebabkan sakit termasuk terjadinya skizofrenia. ${ }^{17,18} \mathrm{Hal}$ lain yang berkontribusi terhadap kejadian skizofrenia adalah status pernikahan. Durkheim mengatakan bahwa pernikahan dapat mengurangi isolasi sosial dan perasaan kesepian. Perlindungan dari pasangan hidup membuat ikatan batin secara finansial, fisiologis, dan psikologis antar 
pasangan meskipun tidak semua pasangan dapat menyediakan perlindungan. Seseorang yang jarang berkomunikasi dan membina hubungan yang suportif cenderung semakin merasa kesepian. ${ }^{19}$ Sedangkan untuk status pendidikan, sebagian besar responden berpendidikan SMP dan SMA (27,30\%).Pendidikan rendah dapat menjadi penyebab terjadinya masalah psikologis. Individu dengan pendidikan rendah akan kesulitan dalam menyampaikan ide, gagasan atau pendapatnya, sehingga memengaruhi cara berhubungan dengan orang lain, menyelesaikan masalah, membuat keputusan dan responsnya terhadap sumber stress. ${ }^{1}$

\section{Perubahan Aspek Sosial Tanda dan \\ Gejala Isolasi Sosial}

SST dan CBSST dapat menurunkan tanda dan gejala sosial pada pasien dengan isolasi sosial. Pada tabel 1 dan 2 terlihat bahwa hasil penelitian pada kelompok pertama yang mendapatkan tindakan ners generalis dan SST menunjukkan penurunan tanda dan gejala isolasi sosial $74,32 \%$. Sedangkan, pada kelompok kedua yang mendapatkan tindakan ners generalis dan CBSST menunjukkan penurunan $64,05 \%$.

Tabel 1. Tanda Gejala Sosial Sebelum dan Sesudah Tindakan Ners Generalis dan SST $(n=11)$

\begin{tabular}{|c|c|c|c|c|c|c|}
\hline \multirow[b]{2}{*}{ No } & \multirow[b]{2}{*}{ Tanda dan Gejala Sosial } & \multicolumn{5}{|c|}{ Frekuensi } \\
\hline & & Pre & $\%$ & Post & $\%$ & $\begin{array}{l}\text { Penurunan } \\
(\%)\end{array}$ \\
\hline 1 & Menarik diri & 7 & 63.64 & 0 & 0 & 100 \\
\hline 2 & Sulit berinteraksi & 4 & 36.36 & 0 & 0 & 100 \\
\hline 3 & Enggan berkomunikasi dengan orang lain & 4 & 36.36 & 0 & 0 & 100 \\
\hline 4 & $\begin{array}{l}\text { Kegagalan berinteraksi dengan orang lain yang } \\
\text { ada didekatnya }\end{array}$ & 9 & 81.82 & 2 & 18,18 & 77,78 \\
\hline 5 & $\begin{array}{l}\text { Ketidakmampuan berpartisipasi dalam kegiatan } \\
\text { sosial }\end{array}$ & 8 & 72.73 & 5 & 45,45 & 37,49 \\
\hline 6 & Tidak peduli dengan lingkungan & 10 & 90.91 & 7 & 63,64 & 30 \\
\hline 7 & Curiga terhadap orang lain & 4 & 36.36 & 1 & 9,09 & 75 \\
\hline & Rerata & 6,57 & 59,74 & 2,14 & 19,48 & 74,32 \\
\hline
\end{tabular}

Ruang Utari RSMM Bogor, 2016

Tabel 2. Tanda Gejala Sosial Sebelum dan Sesudah Tindakan Ners Generalis dan CBSST( $n=11)$

\begin{tabular}{|c|c|c|c|c|c|c|}
\hline \multirow[b]{2}{*}{ No } & \multirow[b]{2}{*}{ Tanda dan Gejala } & \multicolumn{5}{|c|}{ Frekuensi } \\
\hline & & Pre & $\%$ & Post & $\%$ & $\begin{array}{c}\text { Penurunan } \\
(\%)\end{array}$ \\
\hline 1 & Menarik diri & 5 & 45,45 & 0 & 0 & 100 \\
\hline 2 & Sulit berinteraksi & 5 & 45,45 & 0 & 0 & 100 \\
\hline 3 & Enggan berkomunikasi dengan orang lain & 4 & 36,36 & 1 & 9,09 & 75 \\
\hline 4 & $\begin{array}{l}\text { Kegagalan berinteraksi dengan orang lain } \\
\text { yang ada didekatnya } \\
\text { Ketidakmampuan berpartisipasi dalam }\end{array}$ & 10 & 90,91 & 2 & 18,18 & 80 \\
\hline & kegiatan sosial & 9 & 81,82 & 6 & 54,55 & 33,33 \\
\hline 6 & Tidak peduli dengan lingkungan & 10 & 90,91 & 9 & 81,82 & 10 \\
\hline 7 & Curiga terhadap orang lain & 4 & 36,36 & 2 & 18,18 & 50 \\
\hline
\end{tabular}




\begin{tabular}{|c|c|c|c|c|c|c|}
\hline \multirow[b]{2}{*}{ No } & \multirow[b]{2}{*}{ Tanda dan Gejala } & \multicolumn{5}{|c|}{ Frekuensi } \\
\hline & & Pre & $\%$ & Post & $\%$ & $\begin{array}{c}\text { Penurunan } \\
(\%)\end{array}$ \\
\hline & & 6,71 & 61,04 & 2,86 & 25,97 & 64,05 \\
\hline
\end{tabular}

Ruang Utari RSMM Bogor, 2016

Penurunan tanda dan gejala sosial pada kelompok yang memperoleh SST lebih besar dibandingkan kelompok yang memperoleh CBSST. SST adalah terapi yang berorientasi pada tugas dan membentuk perilaku baru. SST digunakan untuk meningkatkan dan membentuk komunikasi yang fleksibel sehingga klien mampu berespons dengan baik terhadap situasi yang beragam. Peran perawat disini adalah memberikan penguatan positif, menjadi role model, tolok ukur, terapis, dan membentuk pola perilaku sosialisasi klien yang diharapkan. ${ }^{7}$ Selain itu, SST meningkatkan perilaku asertif, kemampuan pasien untuk mengekspresikan perasaannya, emosi, kebutuhan, dan pendapat pribadi dengan jelas dan efektif tanpa ada rasa cemas, takut, ketidaknyamanan dan agresif. ${ }^{20}$ SST tidak banyak memberikan perubahan pada aspek kognitif karena tidak difokuskan pada kemampuan pasien untuk merubah pikiran terkait sosialisasi. Pasien banyak berfokus pada latihan dan kegiatan yang menggunakan aktivitas fisik. Berbeda dengan CBSST. Perubahan tanda dan gejala pasien isolasi sosial dengan CBSST cukup signifikan pada aspek kognitif, dan afektif.Terapi kognitif yang ada pada CBSST menguji efek pikiran maladaptif pada pasien gangguan jiwa terhadap afek dan perilaku, karena ketiganya memiliki hubungan saling memengaruhi pada perilaku isolasi sosial khususnya. ${ }^{16}$

\section{Perubahan Kemampuan Sosialisasi}

Hasil penelitian menunjukkan bahwa kemampuan bersosialisasi pasien dengan isolasi sosial meningkat setelah diberikan SST dan CBSST. Pada tabel 3 dan 4 terlihat bahwa kelompok pertama yang mendapatkan tindakan ners generalis dan SST menunjukkan peningkatan kemampuan sosialisasi 87,65\%. Sedangkan, pada kelompok kedua yang mendapatkan tindakan ners generalis dan CBSST menunjukkan peningkatan kemampuan sosialisasi $93.54 \%$.

Tabel 3. Kemampuan Sosialisasi Sebelum dan Sesudah Tindakan Ners Generalis dan SST $(n=11)$

\begin{tabular}{|c|c|c|c|c|c|c|}
\hline \multirow{2}{*}{ No } & \multirow[b]{2}{*}{ Kemampuan } & \multicolumn{4}{|c|}{ Frekuensi } & \multirow{2}{*}{$\begin{array}{c}\text { Peningkatan } \\
(\%)\end{array}$} \\
\hline & & Pre & $\%$ & Post & $\%$ & \\
\hline 1 & Bersosialisasi & 4 & 18,18 & 11 & 100 & 81,82 \\
\hline 2 & Menjalin persahabatan & 3 & 13,64 & 10 & 90,91 & 85 \\
\hline 3 & $\begin{array}{l}\text { Bekerja sama dalam } \\
\text { kelompok }\end{array}$ & 1 & 4,55 & 7 & 63,64 & 92,85 \\
\hline \multirow[t]{2}{*}{4} & Menghadapi situasi sulit & 0 & 0 & 10 & 90,91 & 90,91 \\
\hline & Rerata & 2 & 9,09 & 9.5 & 86,37 & 87,65 \\
\hline
\end{tabular}

Ruang Utari RSMM Bogor, 2016 
Tabel 4. Kemampuan Sosialisasi Sebelum dan Sesudah Tindakan Ners Generalis dan CBSST $(n=11)$

\begin{tabular}{|c|c|c|c|c|c|c|}
\hline No & Kemampuan & Pre & $\%$ & Post & $\%$ & $\begin{array}{c}\text { Peningkatan } \\
(\%)\end{array}$ \\
\hline 1 & Merubah pikiran negatif 1 & 0 & 0 & 11 & 100 & 100 \\
\hline 2 & Merubah pikiran negatif 2 & 0 & 0 & 8 & 72,73 & 100 \\
\hline 3 & Bersosialisasi & 4 & 18,18 & 11 & 100 & 81,82 \\
\hline 4 & Menjalin persahabatan & 3 & 13,64 & 10 & 90,91 & 85 \\
\hline 5 & $\begin{array}{l}\text { Bekerja sama dalam } \\
\text { kelompok }\end{array}$ & 1 & 4,55 & 9 & 81,82 & 94,44 \\
\hline \multirow[t]{2}{*}{6} & Menghadapi situasi sulit & 0 & 0 & 11 & 100 & 100 \\
\hline & Rerata & 1,33 & 6,06 & 10 & 90,91 & 93,54 \\
\hline
\end{tabular}

Ruang Utari RSMM Bogor, 2016

Pasien mendapatkan tindakan ners generalis yaitu latihan berkenalan secara bertahap untuk melatih ketrampilan sosial pasien sehingga merasa nyaman dalam situasi sosial dan dapat melakukan interaksi sosial dengan orang lain serta lingkungannya. Tujuan yang diharapkan setelah dilakukan tindakan ners generalis, pasien mampu membina hubungan saling percaya dengan orang lain, menyadari penyebab isolasi sosial dan mampu berinteraksi dengan orang lain secara bertahap. $^{21}$

Pada tindakan SST yang terlihat pada tabel 3, peningkatan kemampuan lebih banyak pada kemampuan pasien untuk bekerja sama dalam kelompok (92,85\%). Ballinger dan Yalom (1996) menjelaskan bahwa peran terapeutik kelompok bersifat here and now. Kelompok mengajarkan bagaimana individu berinteraksi dengan orang lain untuk membantu memenuhi kebutuhannya dan mendiskusikan caranya, mengarahkan pada perubahan perilaku, pikiran dan spiritual.Hasilnya akan efektif jika perilaku tersebut dilakukan berulang-ulang. ${ }^{22}$
Pengulangan tiap sesi dilakukan di ruangan masing-masing. Pasien terus dimotivasi untuk mau bekerja sama dalam kegiatan-kegiatan harian di ruangan seperti membereskan tempat tidur dan mengatur piket untuk menyiapkan makan.SST yang ditujukan untuk memandirikan pasien dalam bersosialisasi, kemampuannya dapat diukur tiap bulan hingga tahunan. Pasien harus memiliki kesempatan untuk mempraktikkan ketrampilannya dalam kehidupan nyata untuk digunakan di masyarakat sekembalinya dari perawatan. ${ }^{22}$

Keberhasilan SST dalam merubah tanda gejala dan kemampuan pasien tertuang dalam beberapa karya tulis ilmiah. SST yang dikombinasikan dengan Family Psychoeducation (FPE) dapat menurunkan tanda dan gejala serta meningkatkan kemampuan pasien dengan halusinasi dan isolasi sosial. $^{23}$ Sedangkan pada penelitian lainnya menunjukkan bahwa dengan SST yang dilakukan dengan pendekatan teori Peplau dan Henderson dapat memudahkan perawat dalam berinteraksi dengan pasien isolasi sosial. ${ }^{10}$ 
CBSST pada tabel 4 menunjukkan bahwa peningkatan kemampuan pasien terbanyak adalah pada kemampuan pasien dalam merubah pikiran negatif terkait penyebab perilaku isolasi sosial dan kemampuan menghadapi situasi sulit (100\%). Terapi kognitif yang menjadi bagian CBSST membantu pasien memperbaiki distorsi kognitif yang dialaminya. Distorsi kognitif yang banyak muncul pada pasien isolasi sosial diantaranya adalah junk to the conclusion, dan decathastripizing.CBSST pada pasien skizofrenia yang diberikan selama 9 bulan dan 36 sesi pada pasien usia 26-55 tahun sebanyak 213 orang menunjukkan peningkatan ketrampilan fungsi sosial dan fungsi kognitif. ${ }^{24}$ Senada dengan penelitian Jumaini (2010) yang menunjukkan bahwa CBSST dapat meningkatkan kemampuan kognitif pasien isolasi sosial sebanyak $80,35 \%$. $^{25}$

\section{KESIMPULAN}

Hasil pengkajian pada pasien isolasi sosial di Ruang Utari didapatkan semua pasien berjenis kelamin perempuan, berusia dewasa, tingkat pendidikan adalah tamat SMP dan SMA, tidak bekerja, dan menikah. Penurunan tanda dan gejala pada aspek sosial lebih banyak terlihat pada kelompok pasien yang mendapatkan tindakan ners generalis dan SST dibandingkan CBSST. Sedangkan, kemampuan sosialisasi pasien lebih banyak mengalami peningkatakn pada kelompok pasien yang mendapatkan tindakan ners generalis dan CBSST dibandingkan SST.

Hasilnya dapat menjadi dasar untuk penyediaan Standar Asuhan Keperawatan (SAK) sebagai acuan perawat dalam melakukan manajemen asuhan keperawatan pada pasien dengan isolasi sosial secara berkesinambungan dengan melibatkan perawat generalis dan spesialis, serta melibatkan semua unsur penyedia layanan asuhan keperawatan termasuk mahasiswa dalam membangun hubungan kolaboratif. Menetapkan kebijakan yang jelas terkait uraian tugas yang disahkan dalam surat keputusan direktur diimbangi dengan sistem pengawasan yang komprehensif sehingga dapat mempertahankan sustainability pelaksanaan Model Praktek Keperawatan Profesional (MPKP) sehingga dapat meningkatkan mutu layanan rumah sakit dan tingkat kepuasan.

\section{KEPUSTAKAAN}

1. Stuart, G.W. Prinsip dan Praktik Keperawatan Kesehatan Jiwa Stuart. Edisi Indonesia. Buku 1. Elseiver: Singapura. 2015.

2. WHO. Improving Health System and Service for Mental Health: WHO library cataloguing in publication data. 2009.

3. Riskesdas. Riset Kesehatan Dasar (Riskesdas 2013). Jakarta: Badan Penelitian dan Pengembangan Kesehatan Kementerian Kesehatan RI Tahun 2013. 2013.

4. WHO. Skizophrenia. Diakses pada $25 \mathrm{Mei}$ 2016 http://www.who.int/mediacentre/factsheets/ fs397/en/. 2016.

5. Shives LR. Basic Concept of PsychiatricMental Health Nursing. 8th edition. Lippincott William \& Wilkins. 2012. 
6. NANDA. Diagnosis Keperawatan: Definisi dan Klasifikasi 2015-2017. Jakarta: EGC. 2015.

7. Malky, M.I., Attia, M.M., \& Alam, F.H. The effectiveness of social skill training on depressive symptoms, self-esteem and interpersonal difficulties among schizophrenic patiens. International journal of advanced nursing studies. Doi: 10.14419/ijans.v511.5386. Diakses pada tanggal 23 Maret 2016 di www.Sciencepubco.com/index.php/LIANS. 2016.

8. Bellido, Zanin, G., Perez-San-Gregorio, M., Martin-Rodriguez., et al. Social Functioning as a Predictor of Use of Mental Health Resources in Patiens with Severe Mental Disorder. Psychiatric research. 230. 0.189-193. Diakses pada tanggal $12 \quad$ Maret 2016di http://dx.doi.org/10.1016/j.psychres.2015.0 8.037. 2015.

9. Raudino, A., Carr, V.J., Bush, R., Saw, S., Burgess, P., Morgan, V.A., 2014. Patterns ofservice utilisation in psychosis: findings of the 2010 Australian national survey of psychosis. Aust. N. Z. J. Psychiatry 48, 341-351. Diakses pada tanggal 16 Maret 2016.

10. Putri, D.E. Penerapan asuhan keperawatan pada pasien isolasi sosisl dengan pendekatan model konseptual Hildegard E. Peplau dan Virginia Henderson. Ners Jurnal Keperawatan. 2012. Vol. 8. No.1.

11. Kirana, S.A.C., Keliat, BA., \&Mustikasari. Pengaruh Cognitive Behavioral Social Skills Training terhadap Gejala Klien Halusinasi dan Isolasi Sosial di Rumah Sakit. Tesis FIK UI. Tidak Dipublikasikan. 2015.

12. Syukri,M., Keliat, BA., \& Mustikasari. Penerapan Cognitive-Behavior Social Skills Training pada Klien Halusinasi dan Isolasi Sosial dengan Pendekatan Model Hubungan Interpersonal Peplau di RS dr. Marzoeki Mahdi Bogor. Karya Ilmiah Akhir. FIK UI. Tidak Dipublikasikan. 2014.

13. Keliat, B.A.,\&Prawirowiyono, A. Keperawatan Jiwa: Terapi Aktifitas Kelompok. EGC: Jakarta. 2016.
14. Fortinash., Worret H. Psychiatric Mental Health Nursing. (5th edition). Philadelphia: Elseiver. 2012.

15. Gierveld, Jong J. de, Tilburg, T. Van \& Dykstra, P.A. Loneliness and Social Isolation In: Vangelisti, A. \& Perlman, D., The Cambridge handbook of personal relationships. New York p. 485-500. 2006.

16. Sinaga, B.R. Skizofrenia \& Diagnosis Banding. Balai Penerbit, Fakultas Kodokteran-Universitas Indonesia, Jakarta. 2007.

17. Sharf, R.S. Theories of psychotherapy and counseling: concept and cases. (5th edition). Maerica: Brooks/cole cengage learning. 2012.

18. Hawari, D. Pendekatan Holistik Pada Gangguan Jiwa Skizofrenia. Jakarta: FIK UI. 2007.

19. Townsend, MC Psychiatric Mental Health Nursing Concepts of Care in EvidenceBased Practice. 6th edition. Davis Plus Company: Philadelphia. 2014.

20. Gierveld, Jong J. de, Tilburg, T. van \& Dykstra, P.A. Loneliness and Social Isolation In: Vangelisti, A. \& Perlman, D., The Cambridge handbook of personal relationships. New York p. 485-500. 2005.

21. Bucci, P., Piegari, G., Mucci, A., Merlotti, E., Chieffi, M., De Riso, F., De Angelis, M., Di Munzio, W., \& Galderisi, S. Neurocognitive Individual Training vs Social Skills Individualized Training: A Randomize Trial in Patients with Schizophrenia. Schizophrenia research. Diakses pada tanggal 25 Mei 2016 di http://dx.doi.org/10.1016/j.schres.2013.07. 053. 2013.

22. Keliat, B.A. Keperawatan Kesehatan Jiwa Komunitas: CMHN (Basic Course). EGC: Jakarta. 2011.

23. Fontaine, K.L. Mental health Nursing. 6th edition. Pearson Education: New Jersey. 2009.

24. Sukaesti, D., Hamid, AYS,. \& Wardani, IY. Manajemen Asuhan keperawatan Spesialis Jiwa pada Klien Isolasi Sosial dan Risiko Perilaku Kekerasan menggunakan Pendekatan Hubungan Interpersonal Peplau dan Stuart di Ruang Gatotkaca RSMM. Karya IImiah Akhir. FIK UI. Tidak Dipublikasikan. 2015. 
25. Granholm, E., Ben-Zeef, D., dan Link, P,C,. Social Disinterest Attitudes an Group Cognitive Behavioral Social Skills Training for Functional Disability in Schizophrenia. Shizophrenia Bulletin, 35(5), 874-883. 2009.
26. Jumaini., Keliat, BA., \& Daulima, NH. Pengaruh Cognitive Behavioral Social Skills Training (CBSST) terhadap Kemampuan Bersosialisasi Klien isolasi Sosial di BLU RS. Dr. H. Marzoeki Mahdi Bogor. Tesis FIK UI. Tidak Dipublikasikan. 2010. 